Article

\title{
Chemical and Biological Evaluation of Essential Oils from Two Species of Myrtaceae - Eugenia uniflora L. and Plinia trunciflora (O. Berg) Kausel
}

João Henrique G. Lago ${ }^{1}$, Elisângela Dutra Souza ${ }^{1}$, Bruna Mariane ${ }^{1}$, Renata Pascon ${ }^{1}$, Marcelo A. Vallim ${ }^{1}$, Roberto Carlos C. Martins ${ }^{2}$, Adriana A. Baroli ${ }^{2}$, Bianca A. Carvalho ${ }^{3}$, Marisi G. Soares ${ }^{3}$, Roberta T. dos Santos ${ }^{1}$ and Patricia Sartorelli ${ }^{1, *}$

1 Instituto de Ciências Ambientais, Químicas e Farmacêuticas, Universidade Federal de São Paulo, Campus Diadema 09972-270, SP, Brasil

2 Centro de Estudos Químicos, UNIFIEO, Centro Universitário FIEO, Osasco 06020-190, SP, Brasil

3 Instituto de Química, Universidade Federal de Alfenas, Alfenas 37130-000, MG, Brasil

* Author to whom correspondence should be adressed; E-Mail: psartorelli@unifesp.br; Tel.: +55-11-3319-3300; Fax: +55-11-4043-6428.

Received: 8 October 2011; in revised form: 18 November 2011 / Accepted: 18 November 2011 / Published: 25 November 2011

\begin{abstract}
The chemical composition and antimicrobial activity of essential oils obtained from leaves of two Myrtaceae species-Eugenia uniflora L. and Plinia trunciflora (O. Berg) Kausel-were determined. Analysis by GC/MS as well as determination of Kovatz indexes indicated atractylone $(26.78 \%)$ and curzerene $(17.96 \%)$ as major constituents of E. uniflora oil and $\alpha$-cadinol (19.15\%), apiole (11.15\%) and cubenol (5.43\%) as main components in P. trunciflora oil. Both essential oils were tested for antimicrobial activity against yeasts and bacteria. E. uniflora and P. trunciflora essential oils were active towards two Gram-positive bacteria, Streptococcus equi and Staphylococcus epidermis. In addition, biological activity of both essential oils was detected for pathogenic yeasts of the genus Candida and Cryptococcus. E. uniflora was active towards all yeast tested and exhibited interesting minimal inhibitory concentrations ( 0.11 to $3.75 \mathrm{mg} / \mathrm{mL})$ across a broad spectrum of activity.
\end{abstract}

Keywords: Eugenia uniflora L.; Plinia trunciflora (O. Berg) Kausel; essential oils; antimicrobial activity 


\section{Introduction}

The Myrtaceae comprise 4,620 species distributed in 140 genera whose occurrence has been described in tropical and subtropical regions of the World, mainly Australia and Central and South America [1]. The main genera are Myrtus, Psidium, Pimenta, Eugenia, Pseuocaryophyllus, Syzygium, Eucalyptus, Leptospermum, Plinia, and Malaleuca. Several members of this family are used in folk medicine as antidiarrheal, antimicrobial, antioxidant, antirheumatic, anti-inflammatory, and cleansing agents, and they are also used to decrease blood cholesterol [2]. Chemically, several members mainly accumulate flavonoids, tannins and other phenolic derivatives [3-5]. In addition, this family represents an important source of essential oils with biological activities ranging from bacteriostatic and fungistatic to anti-inflammatory [6], which have been used as antimicrobial and antifungal agents in creams, soaps, and toothpastes [7].

The chemical composition of essential oils from several species of Eugenia was previously described in the literature, especially those from E. uruguayensis Camb. [8], E. banderensis Urb. [9], E. nitida Camb. [10], E. brasiliensis Lam. [11], and E. uniflora L. [12-14]. Sesquiterpenes (hydrocarbon and oxygenated derivatives) were found as the main class of volatile constituents possessing antibacterial, antifungal, anti-inflammatory, and cytotoxic activities [6]. In addition to these derivatives, monoterpenes and phenylpropanoids were also described in these oils.

Eugenia uniflora L., popularly known as "pitangueira", is a highly appreciated species in Brazil due to its reddish fruits with a sweet taste, and tea obtained from its leaves has been used in folk medicine against fever, stomach diseases, hypotension, and gout, and as a hypoglycemiant [15,16]. Plinia is another genus of Myrtaceae that shows several traditional uses and is also a source of essential oils composed mainly of sesquiterpenes [17,18]. Plinia trunciflora (O. Berg) Kausel, a synonym of Myrciaria truncifloraI Mart. (O. Berg), is popularly named "jabuticabeira" in Brazil and its edible fruits are also appreciated. In folk medicine, species of Plinia have been used in the treatment of stomach disorders, throat afflictions, and diabetes [19]. Biological properties of essential oil from P. trunciflora have not been reported, but leaf extract showed antioxidant and antimicrobial activities [20]. In a continuation of our systematic studies on pharmacologically active volatiles from Brazilian plants [21,22] we describe in this paper an evaluation of the chemical composition and antimicrobial activity of essential oils from leaves of $E$. uniflora and, for the first time, antimicrobial activity of essential oil from the leaves of $P$. trunciflora.

\section{Results and Discussion}

Hydrodistillation of the fresh leaves from E. uniflora afforded a yellow viscous oil with a pungent odor (yield $0.1 \% \mathrm{w} / \mathrm{w}$ ), while P. trunciflora provided an odorless and colorless oil (yield $0.02 \% \mathrm{w} / \mathrm{w}$ ). The constituents of essential oil of E. uniflora and P. trunciflora were analyzed by GC-FID-MS followed by calculation of Kovatz indexes. In total, 56 compounds were identified (Table 1) accounting for 77.16 and $72.92 \%$ of the total oil composition of E. uniflora and P. trunciflora, respectively. In both oils, oxygenated sesquiterpenes were the major constituents (E. uniflora: 49.89\%; P. trunciflora: 48.09\%), but hydrocarbon sesquiterpenes (24.79\%) were also identified in E. uniflora. Monoterpenes were present in smaller concentrations in both oils, but hydrocarbon monoterpene occurrence was restricted to 
E. uniflora (2.32\%), while oxygenated derivatives were dominant in P. trunciflora (13.34\%). In addition, phenylpropanoids were present in lower concentrations in E. uniflora $(0.09 \%)$ and in higher amounts in P. trunciflora, mainly due to the presence of apiole (11.15\%).

Table 1. Chemical composition of essential oil from leaves of E. uniflora and P. trunciflora.

\begin{tabular}{|c|c|c|c|}
\hline Compound & KI & E. uniflora & P. trunciflora \\
\hline$\beta$-pinene & 980 & 0.22 & \\
\hline$\alpha$-phellandrene & 1005 & 0.05 & - \\
\hline ortho-cymene & 1022 & 0.09 & - \\
\hline sylvestrene & 1027 & 0.08 & - \\
\hline$(Z)$ - $\beta$-ocimene & 1040 & 0.51 & - \\
\hline$(E)$ - $\beta$-ocimene & 1050 & 1.24 & - \\
\hline$\gamma$-terpinene & 1062 & 0.05 & - \\
\hline terpinolene & 1088 & 0.08 & - \\
\hline linalool & 1098 & 0.04 & - \\
\hline neo-menthol & 1165 & - & 1.86 \\
\hline hexenyl butyrate & 1186 & 0.03 & - \\
\hline$\alpha$-terpineol & 1189 & - & 7.48 \\
\hline n-dodecane & 1199 & - & 0.36 \\
\hline trans-pulegol & 1213 & - & 0.48 \\
\hline anethole & 1251 & 0.09 & - \\
\hline isobornyl acetate & 1285 & - & 0.41 \\
\hline$\delta$-elemene & 1339 & 0.16 & - \\
\hline$\alpha$-copaene & 1376 & 0.08 & \\
\hline$\gamma$-elemene & 1433 & 0.22 & - \\
\hline$\alpha$-humulene & 1454 & 0.25 & - \\
\hline$\gamma$-muurolene & 1477 & 3.59 & - \\
\hline$\beta$-selinene & 1485 & 0.21 & - \\
\hline viridiflorene & 1493 & 0.08 & - \\
\hline curzerene & 1496 & 17.96 & - \\
\hline$\alpha$-muurolene & 1499 & 0.12 & - \\
\hline$\alpha$-bisabolene & 1504 & 1.35 & - \\
\hline$\delta$-cadinene & 1524 & 0.50 & - \\
\hline$\alpha$-cadinene & 1538 & 0.09 & - \\
\hline selina-3,7(11)-diene & 1542 & 0.18 & - \\
\hline elemol & 1549 & 0.02 & - \\
\hline germacrene B & 1556 & 9.31 & - \\
\hline ledol & 1565 & - & 1.80 \\
\hline caryophyllene alcohol & 1568 & 0.72 & - \\
\hline spathulenol & 1576 & 1.08 & - \\
\hline viridiflorol & 1590 & 3.08 & 2.74 \\
\hline longiborneol & 1592 & 2.09 & - \\
\hline 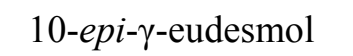 & 1619 & - & 0.48 \\
\hline 3-iso-thujopsanone & 1637 & 0.27 & - \\
\hline
\end{tabular}


Table 1. Cont.

\begin{tabular}{cccc}
\hline Compound & KI & E. uniflora & P. trunciflora \\
\hline epi- $\alpha$-cadinol & 1640 & 0.41 & 3.29 \\
epi- $\alpha$-muurolol & 1641 & 1.37 & - \\
cubenol & 1641 & 0.44 & 5.43 \\
$\alpha$-muurolol & 1645 & - & 2.82 \\
vulgarone B & 1647 & - & 2.65 \\
atractylone & 1653 & 26.78 & - \\
$\alpha$-cadinol & 1653 & - & 19.15 \\
valerianol & 1655 & - & 0.85 \\
5-hydroxyisobornyl isobutyrate & 1655 & - & 2.75 \\
valeranone & 1672 & - & 2.78 \\
apiole & 1680 & - & 11.15 \\
iso-longifolol & 1726 & - & 1.28 \\
coniferyl alcohol (E) & 1729 & - & 1.84 \\
zerumbone & 1731 & 4.18 & - \\
6R,7R-bisabolone & 1737 & 0.11 & - \\
$\alpha$-sinensal & 1752 & - & 0.88 \\
8-cedren-13-ol acetate & 1795 & 0.03 & - \\
nootkatone & 1800 & - & 2.14 \\
\hline Hydrocarbon monoterpenes & & 2.32 & - \\
Oxygenated monoterpenes & & 0.04 & 13.34 \\
Hydrocarbon sesquiterpenes & & 24.79 & - \\
Oxygenated sesquiterpenes & & 48.89 & 48.03 \\
Phenylpropanoids & & 0.09 & 11.15 \\
Other compounds & & 0.03 & 0.36 \\
\hline TOTAL & & $\mathbf{7 7 . 1 6}$ & $\mathbf{7 2 . 9 2}$ \\
\hline
\end{tabular}

Although the analyzed oils were composed mainly of sesquiterpenes, only three components were detected in both E. uniflora and P. trunciflora oils: Viridiflorol (3.08 and 2.74\%), epi- $\alpha$-cadinol (0.41 and 3.29\%), and cubenol (0.44 and 5.43\%). Atractylone (26.78\%) was the main component of essential oil from E. uniflora, followed by curzerene (17.96\%), which was responsible for the pungent odor detected in the analyzed oil [6]. Essential oils from E. uniflora leaves collected in several localities were previously studied and, despite variation in their chemical compositions, the predominance of sesquiterpenes was confirmed, except in an Argentinean specimen rich in monoterpenes [23]. Moreover, atractylone and curzerene (a Cope rearrangement product of the former), were detected as the main components from other studied specimens of E. uniflora [24-26]. Surprisingly, selina-1,3,7(11)-trien-8-one was previously found to be a main constituent of essential oils from leaves of four species of E. uniflora [25,27-29], but was not detected in the present work.

Analysis of the essential oil of $P$. truncifolia showed that $19.15 \%$ of the total constitution was due to the oxygenated sesquiterpene $\alpha$-cadinol. Other major identified components $(>5 \%)$ were apiole $(11.15 \%), \alpha$-terpineol $(7.48 \%)$, and cubenol (5.43\%). Despite the chemical composition of essential oil from leaves of $P$. trunciflora already being described from a specimen collected in 
Southern Brazil, the obtained results showed some important differences, since in the previous study spathulenol and caryophyllene oxide were identified as the main components [17].

Antimicrobial Activity. To confirm the results found by this semi-quantitative method, a minimum inhibitory concentration (MIC) assay was applied to all positive strains. Table 2 presents the relevant data for the disk diffusion assay expressed as inhibition zone (IZ) and MICs for those strains sensitive to the presence of the two separate essential oils, where numbers in parenthesis represent the average percentage inhibition and standard deviation of three repetitions. For comparison, chloramphenicol (bacteria) and fluconazole (yeast) were used as standards in the disk diffusion assay (MICs ranged from $0.006-0.400 \mathrm{mg} / \mathrm{mL}$ for all tested microorganisms, as showed in Table 2). According to the literature [30], the minimum inhibitory concentration of fluconazole for Candida spp., Cryptoccocus spp. and $S$. cerevisiae ranges from 0.00012 to $0.064,0.00025$ to 0.032 and 0.00012 to $0.016 \mathrm{mg} / \mathrm{mL}$, respectively. Variations in MICs may depend upon genetic variation among strains. As shown in Table 2, our results were consistent with the literature, which guaranteed that our MICs were a reliable tool to demonstrate the biological activity of both essential oils.

Table 2. Antimicrobial activity of two essential oils (from E. uniflora and P. trunciflora) evaluated by the disk diffusion method (IZ) and minimal inhibitory concentration (MIC).

\begin{tabular}{|c|c|c|c|c|c|}
\hline \multirow[b]{2}{*}{ Strains } & \multicolumn{2}{|c|}{ Eugenia uniflora } & \multicolumn{2}{|c|}{ Plinia trunciflora } & \multirow{2}{*}{$\begin{array}{c}\text { Positive control } \\
\text { MIC } \\
(\mathrm{mg} / \mathrm{mL})\end{array}$} \\
\hline & $\begin{array}{c}\mathrm{IZ} \\
(\mathrm{mm}) \\
\end{array}$ & $\begin{array}{c}\text { MIC } \\
(\mathrm{mg} / \mathrm{mL})\end{array}$ & $\begin{array}{c}\mathrm{IZ} \\
(\mathrm{mm})\end{array}$ & $\begin{array}{c}\text { MIC } \\
(\mathrm{mg} / \mathrm{mL})\end{array}$ & \\
\hline S. equi & 1.4 & $7.50(55 \pm 6 \%)$ & 1.4 & $0.12(94 \pm 3 \%)$ & $0.025 * *$ \\
\hline S. epidermidis & 1.6 & $7.50(87 \pm 2 \%)$ & 1.6 & $0.12(95 \pm 4 \%)$ & $0.400 * *$ \\
\hline C. dubliniensis & 1.4 & $0.23(93 \pm 22 \%)$ & 1.2 & $0.06(99 \pm 5 \%)$ & $0.006^{*}$ \\
\hline C. tropicalis & 1.4 & $0.90(85 \pm 1 \%)$ & - & - & $0.050 *$ \\
\hline C. albicans & 1.4 & $1.80(93 \pm 1 \%)$ & 1.4 & $0.06(82 \pm 6 \%)$ & $0.025 *$ \\
\hline C. glabrata & 1.6 & $0.93(85 \pm 8 \%)$ & 1.4 & $0.12(100 \pm 0 \%)$ & $0.050 *$ \\
\hline C. parapsilosis & 1.4 & $3.75(85 \pm 1 \%)$ & 1.4 & $0.12(98 \pm 5 \%)$ & $0.006 *$ \\
\hline C. grubii (serotype A) & 1.6 & $0.45(89 \pm 2 \%)$ & 1.6 & $0.12(97 \pm 7 \%)$ & $0.013 *$ \\
\hline C. gattii (serotype C) & 1.6 & $1.80(75 \pm 21 \%)$ & 1.2 & $0.12(98 \pm 4 \%)$ & $0.025 *$ \\
\hline C. gattii (serotype B) & 1.6 & $0.22(99 \pm 3 \%)$ & - & - & $0.006 *$ \\
\hline C. neoformans (serotype D) & 1.6 & $0.11(87 \pm 13 \%)$ & - & - & $0.006 *$ \\
\hline S. cerevisiae & 1.6 & $0.22(91 \pm 12 \%)$ & 1.6 & $0.12(100 \pm 0 \%)$ & $0.013 *$ \\
\hline Negative control & 1.0 & NA & 1.0 & NA & NA \\
\hline
\end{tabular}

Numbers in parenthesis represent the average percentage inhibition (three repetitions) and standard deviation at each MIC; Legend: * fluconazole; ** chloramfenicol; - no biological activity detected; NA, does not apply.

None of the Gram-negative strains tested were inhibited, but two Gram-positive strains (S. equi and S. epidermidis) showed growth reduction in the presence of the essential oils. This was in accordance with several other reports where essential oils were shown to be more active towards Gram-positive than Gram-negative bacteria [31-34]. On the other hand, several species of opportunistic pathogens belonging to Candida and Cryptoccocus genus and the model organism $S$. cerevisiae were inhibited by the agents under investigation. Regarding E. uniflora oil, all yeasts except $C$. krusei were inhibited by smaller amounts of crude essential oil $(0.11$ to $1.80 \mathrm{mg} / \mathrm{mL})$ than $C$. parapsilosis, which required higher concentrations of oil for growth inhibition $(3.75 \mathrm{mg} / \mathrm{mL})$. Furthermore, P. trunciflora displayed 
a remarkable effect, except for C. tropicalis, C. krusei and two Cryptoccocus serotypes (C and D), which did not show any growth inhibition.

Regarding the genus Candida, Sokmem et al. [35] reported no antimicrobial activity against C. krusei using methanol extracts of Achillea sintenisii, while the essential oil of this plant showed mild biological activity against $C$. albicans and C. krusei.

Comparison of the two essential oils revealed that the oil from P. trunciflora was more efficient against $C$. albicans than oil obtained from $E$. uniflora leaves $(0.06$ and $1.8 \mathrm{mg} / \mathrm{mL})$. This might be of great pharmaceutical interest because this continues to be the leading cause of disease in immunodeficient patients [36]. A similar profile was detected for C. grubbii (MICs of 0.12 and $0.45 \mathrm{mg} / \mathrm{mL}$ for P. trunciflora and E. uniflora, respectively), which is the major pathogen in fungal meningitis [37].

E. uniflora and $P$. trunciflora oils also demonstrated remarkable biological activity against $S$. cerevisiae ( 0.22 and $0.12 \mathrm{mg} / \mathrm{mL}$, respectively) and C. neoformans $(0.45$ and $0.12 \mathrm{mg} / \mathrm{mL}$, respectively). From a clinical point of view, these results could be important as these essential oils may represent an alternative to antimicrobial treatment. Furthermore, all three yeasts tested are great model pathogens, indicating that they can be employed in genetic studies that will shed some light on the mechanism of action of essential oils leading to growth inhibition. For example, Tamae et al. [38] used a collection of 4,000 E. coli knockout mutants to uncover the genetic basis of different antibiotic actions. These authors reported that the absence of 140 genes caused sensitivity to 7 different antimicrobial substances. The same kind of study could be done with $S$. cerevisiae, C. neoformans and C. albicans because they all have full genome sequences and knockout collections available.

\section{Experimental}

\subsection{Plant Material}

Leaves of Eugenia uniflora and Plinia trunciflora were collected in Osasco City, São Paulo State, Brazil (349966-W/7536935-N) in May 2010. Voucher specimens were compared with those under number SPF 195596/HRCB 51587 deposited in the Herbarium of Parque Ecológico da Pavuna, Botucatu SP, Brazil.

\subsection{Essential Oil Extraction and Analysis}

Fresh leaves ( $200 \mathrm{~g}$ ) of E. uniflora and P. trunciflora were individually extracted over five hours by steam distillation in a Clevenger type apparatus to afford the crude essential oils (E. uniflora: $400 \mathrm{mg}$ and $P$. trunciflora: $20 \mathrm{mg}$ ). The oils were then analyzed by GC and GC-MS and the identification of the individual compounds was achieved by comparison of retention indexes (determined relative to the retention times of a series of $n$-alkanes) on a non-polar column and recorded mass spectra with those available in the system [39]. GC chromatograms were obtained on a Shimadzu GC-2010 gas chromatograph equipped with an FID-detector and an automatic injector (Shimadzu AOC-20i) using a RtX-5 capillary column ( $5 \%$ phenyl, $95 \%$ polydimethylsiloxane, $30 \mathrm{~m} \times 0.32 \mathrm{~mm} \times 0.25 \mu \mathrm{m}$ film thickness, Restek, USA). These analyses were performed by injecting $1.0 \mu \mathrm{L}$ of a $1.0 \mathrm{mg} / \mathrm{mL}$ solution of volatile oil in $\mathrm{CH}_{2} \mathrm{Cl}_{2}$ in a split mode (1:30) employing helium as the carrier gas $(1 \mathrm{~mL} / \mathrm{min})$ under 
the following conditions: injector and detector temperatures of $220^{\circ} \mathrm{C}$ and $250{ }^{\circ} \mathrm{C}$, respectively; oven programmed temperature from $40-240{ }^{\circ} \mathrm{C}$ at $3{ }^{\circ} \mathrm{C} / \mathrm{min}$, holding $5 \mathrm{~min}$ at $240{ }^{\circ} \mathrm{C}$. The percentage compositions of the oil samples were computed by internal normalization from the GC peak areas without using correction for response factors. GC/MS analysis was conducted in a Shimadzu GC-17A chromatograph interfaced with a MS-QP-5050A mass spectrometer. Helium was used as the carrier gas. The MS operating conditions were an ionization voltage of $70 \mathrm{eV}$ and an ion source temperature of $230{ }^{\circ} \mathrm{C}$ with the same conditions described above.

\subsection{Microbial Strains}

To test the antimicrobial activity of essential oil from leaves of E. uniflora and P. trunciflora, Gram-positive, Gram-negative and yeast strains were submitted to a disk diffusion assay. Thus three different dilutions (1:10, 1:20 and 1:50) of the essential oils from E. uniflora and P. trunciflora were tested against seventeen microbial strains, which sources were reported in Table 3.

Table 3. Target strains used for antimicrobial activity assays.

\begin{tabular}{cc}
\hline Species & Designation \\
\hline Bacteria & - \\
\hline Escherichia coli & CBMAI 469 \\
Serratia marcescens & CBMAI 602 \\
Pseudomonas aeruginosa & CBMAI 264 \\
Streptococcus equi & CBMAI 604 \\
Staphylococcus epidermidis & \\
Yeast & ATCC 7978 \\
\hline Candida dubliniensis & ATCC 13803 \\
Candida tropicalis & ATCC 18804 \\
Candida albicans & ATCC 90030 \\
Candida glabrata & Clinical isolate 68 \\
Candida parapsilosis & Clinical isolate 9602 \\
Candida krusei & CBMAI 560 \\
Candida albicans & KN99 (serotype A) \\
Cryptococcus grubii & NIH312 (serotype C) \\
Cryptococcus gattii & R265 (serotype B) \\
Cryptococcus gattii & JEC21 (serotype D) \\
Cryptococcus neoformans & BY4742 \\
Saccharomyces cerevisiae &
\end{tabular}

\subsection{Media, Antibiotics and Growth Conditions}

Yeast were cultivated on agar plates containing YEPD (1\% yeast extract, 2\% peptone, 2\% dextrose and 2\% agar) or RPMI1640 (Sigma). Gram-negative bacteria were grown in LB (0.5\% yeast extract, $1 \%$ tryptone, $1 \% \mathrm{NaCl}$ and $2 \%$ agar) and Gram-positive bacteria were tested in BHI (Himedia). Fluconazole (Sigma) and hygromycin B (Invitrogen) were used as positive controls for yeast and chloramphenicol (Sigma) was the positive control for bacteria. Essential oils were diluted in DMSO or saline $(0.9 \%)$ plus Tween $80(0.5 \%)$. 


\subsection{Disk Diffusion Assay}

Antimicrobial activity was initially evaluated by the disk diffusion method according to the National Committee for Clinical Laboratory Standards (NCCLS, M26-T). Thin agar plates were prepared with $10 \mathrm{~mL}$ of YEPD (yeast), LB (Gram negative) and BHI (Gram positive) media. Three milliliters of liquid cultures were grown at $30{ }^{\circ} \mathrm{C}$ with aeration $(150 \mathrm{rpm}$ ) overnight on YEPD (yeast), LB (Gram-negative) or BHI (Gram positive). A top agar was prepared by mixing each culture $(100 \mu \mathrm{L})$ with soft agar medium for confluent plates (YEPD, LB or BHI plus $1 \%$ agar, $10 \mathrm{~mL}$ ) and poured on top of the thin agar (2\% agar). Sterilized $5 \mathrm{~mm}$ filter paper disks were then impregnated with essential oils diluted in DMSO $(20 \mu \mathrm{L})$. The disks were placed on top of agar plates and incubated at $30{ }^{\circ} \mathrm{C}$ for 24 or 48 hours depending on the microorganism. Hygromycin (1 mg) and chloramphenicol $(200 \mu \mathrm{g})$ were used as positive controls for yeast and bacteria, respectively. Negative control was prepared by impregnating the paper disks with the same amount of DMSO used to dilute the essential oils. All tests were performed in triplicate. The inhibition zone (IZ) was determined by measuring the whole halo diameter divided by the disk size $(5 \mathrm{~mm})$.

Minimum inhibitory concentration. Microdilution tests were conducted in sterile 96 well micro titer plates in a total volume of $100 \mu \mathrm{L}$ according to the National Committee for Clinical Laboratory Standards (NCCLS, M100-S9). Microorganisms were cultured in test tubes overnight at $30^{\circ} \mathrm{C}$ in $3 \mathrm{~mL}$ medium (RPMI 1640 for yeast and BHI for bacteria) in a rotary shaker (150 rpm). The cultures were diluted and adjusted to $1-2 \times 10^{2} \mathrm{CFU} / \mathrm{mL}$, which was confirmed by viability counts on YEPD and BHI plates $(100 \mu \mathrm{L}$ of diluted cells). Essential oils and reference standards were then serial diluted two-fold and tested. A sterilization control containing medium only (negative control) and growth control containing cell and DMSO $(10 \mu \mathrm{L})$ or saline $(10 \mu \mathrm{L})$ and Tween 80 were included as controls. Micro titer plates were then incubated at $30{ }^{\circ} \mathrm{C}$ for 24 or 48 hours depending on the microorganism. Finally, the absorbance at $530 \mathrm{~nm}$ was measured in a plate reader (Logen, MT-960) and the minimum inhibitory concentration was considered the lowest concentration at which at least $80 \%$ of growth was inhibited. All tests were performed in triplicate. The concentration range for each agent was as follows: E. uniflora $7.5-0.11 \mathrm{mg} / \mathrm{mL}$; M. trunciflora $0.12-0.06 \mathrm{mg} / \mathrm{mL}$; fluconazole $0.05-0.0007 \mu \mathrm{g} / \mathrm{mL}$ and chloramphenicol $0.400-0.00312 \mathrm{mg} / \mathrm{mL}$.

\section{Conclusions}

Chemically, the essential oils from leaves of E. uniflora and P. trunciflora showed qualitative differences in respect to identified monoterpenes, sesquiterpenes, and phenylpropanoids. Both analyzed oils displayed interesting antimicrobial activities against several Gram-positive bacteria, mainly $S$. equi and $S$. epidermidis. Additionally, E. uniflora essential oil showed activity against all yeast strains tested, but primarily for $C$. gattii and $C$. neoformans, while $P$. trunciflora oil was active against $C$. dubliniensi and $C$. albicans. These results suggested that the observed activity might be related to the specific composition of sesquiterpenes in the oils. The obtained data clearly indicated that the essential oils of these two species of Myrtaceae could be exploited as antibacterial and fungicide agents. 


\section{Acknowledgments}

This work was supported by FAPESP (2007/50536-3) granted to MAV and (2008/11496-9) granted to PS. We also thank CNPq for the scientific research award to JHGL.

\section{References and Notes}

1. Mabberly, D.J. The Plant Book. A Portable Dictionary of the Vascular Plants, 2nd ed.; Cambridge University Press: Cambridge, UK, 1997.

2. di Stasi, L.C.; Hiruma-Lima, C.A. Plantas Medicinais na Amazônia e na Mata Atlântica, 2nd ed.; Editora Unesp: São Paulo, Brazil, 2002.

3. Kuskoski, E.M.; Vega, J.M.; Rios, J.J.; Fett, R.; Troncoso, A.M.; Asuero, A.G. Characterization of anthocyanins from the fruits of baguaçu (Eugenia umbelliflora Berg). J. Agric. Food Chem. 2003, 51, 5450-5454.

4. Fischer, L.G.; Santos, D.; Serafin, C.; Malheiros, A.; Delle Monache, F.; Delle Monache, G.; Cechinel Filho, V.; de Souza, M.M. Further antinociceptive properties of extracts and phenolic compounds from Plinia glomerata (Myrtaceae) leaves. Biol. Pharm. Bull. 2008, 31, 235-239.

5. Nuengchamnong, N.; Ingkaninan, K. On-line characterization of phenolic antioxidants in fruit wines from family Myrtaceae by liquid chromatography combined with electrospray ionization tandem mass spectrometry and radical scavenging detection. LTW-Food Sci. Technol. 2009, 42, 297-302.

6. Stefanello, M.E.A.; Pascoal, A.C.R.F.; Salvador, M.J. Essential oils from neotropical myrtaceae: Chemical diversity and biological properties. Chem. Biodivers. 2011, 8, 73-94.

7. Lis-Balchin, M.; Hart, S.L.; Deans, S.G. Pharmacological and antimicrobial studies on different tea-tree oils (Melaleuca alternifolia, Leptospermum scoparium or Manuka and Kunzea ericoides or Kanuka), originating in Australia and New Zealand. Phytother. Res. 2000, 14, 623-629.

8. Dellacassa, E.; Lorenzo, D.; Mondello, L.; Cotroneo, A.A. Uruguayan essential oils. Part VII. Composition of leaf oil of Eugenia uruguayensis Camb. Var uruguayensis (Myrtaceae). J. Essent. Oil Res. 1997, 9, 295-297.

9. Bello, A.; Rodriguez, M.L.; Cariñeiras, N.; Urquiola, A.; Rosado, A.; Pino, J.A. Major components of the leaf oil of Eugenia banderesis Urb. J. Essent. Oil Res. 1995, 7, 697-698.

10. Martins, R.C.C.; Alegrio, L.V.; Castro, R.N.; Godoy, R.L.O. Constituents of the essential oil of Eugenia nitida Camb. (Myrtaceae). J. Essent. Oil Res. 1999, 11, 724-726.

11. Lima, N.R.; Cerqueira, S.H.F.; Favero, O.A.; Romoff, P.; Lago, J.H.G. Composition and chemical variation of the essential oil from levaes of Eugenia brasiliensis Lam. and Eugenia sp. J. Essent. Oil Res. 2008, 20, 43-45.

12. Weyerstahl, P.; Marschall-Weyerstahl, H.; Christiansen, C.; Oguntimein, B.O.; Adeoye, A.O. Volatile constituents of Eugenia uniflora leaf oil. Planta Med. 1988, 6, 546-549.

13. Chang, R.; de Morais, S.A.L.; Napolitano, D.R.; Duarte, K.C.; Guzman, V.B.; do Nascimento, E.A. A new approach for quantifying furanodiene and curzerene. A case study on the essential oils of Eugenia uniflora L., Myrtaceae (Pitangueira) leaves. Rev. Bras. Farmacogn. 2011, 21, 392-396. 
14. Gallucci, S.; Neto, A.P.; Porto, C.; Barbizan, D.; Costa, I.; Marques, K.; Benevides, P.; Figueiredo, R. Essential oil of Eugenia uniflora L.: An industrial perfumery approach. J. Essent. Oil Res. 2010, 22, 176-179.

15. Lorenzi, H.; Matos, F.J.A. Plantas Medicinais no Brasil: Nativas e Exóticas Cultivadas; Nova Instituto Plantarum: Odessa, São Paulo, Brazil, 2002.

16. Auricchio, M.T.; Bacchi, E.M. Folhas de Eugenia uniflora L. (pitanga): Propriedades farmacobotânicas, químicas e farmacológicas. Rev. Inst. Adolfo Lutz 2003, 62, 55-61.

17. Apel, M.A.; Sobral, M.; Zuanazzi, J.A.; Henriques, A.T. Essential oil composition of four Plinia species (Myrtaceae). Flavour Fragrance J. 2006, 21, 565-567.

18. Duarte, A.R.; Santos, S.C.; Seraphin, J.C.; Ferri, P.H. Environmental influence on phenols and essential oils of Myrciaria cauliflora leaves. J. Braz. Chem. Soc. 2010, 21, 1672-1680.

19. Bragança, L.A.R. Plantas Medicinais Antidiabéticas. Uma Abordagem Multidisciplinar; Editora da Universidade Federal Fluminense: Niterói, Rio de Janeiro, Brazil, 1996.

20. Souza-Moreira, T.M.; Moreira, R.R.D.; Sacramento, L.V.S.; Pietro, R.C.L.R. Histochemical, phytochemical and biological screening of Plinia cauliflora (Mart.) Kausel (Myrtaceae) leaves. Rev. Bras. Farmacogn. 2010, 20, 48-53.

21. Sartorelli, P.; Marquioreto, A.D.; Lima, M.E.L.; Amaral-Baroli, A.; Moreno, P.R.H. Chemical composition and antimicrobial activity of the essential oils from two species of Eucalyptus. Phytother. Res. 2007, 21, 231-233.

22. Lago, J.H.G.; Carvalho, L.A.C.; da Silva, F.S.; Toyama, D.D.; Favero, O.A.; Romoff, P. Chemical composition and anti-inflammatory evaluation of essential oils from leaves and stem barks from Drimys brasiliensis Miers (Winteraceae). J. Braz. Chem. Soc. 2010, 21, 1760-1765.

23. Urbiego, G.; Taher, H.A.; Talenti, E.C. Chemical composition of essential oil of Eugenia uniflora. An. Asoc. Quim. Argent. 1987, 75, 377-379.

24. Maia, J.G.S.; Andrade, M.H.L.; da Silva, M.H.L.; Zoghbi, M.G.B. A new chemotype of Eugenia uniflora L. from North Brazil. J. Essent. Oil Res. 1999, 11, 727-729.

25. Ogunwande, I.A.; Olawore, N.O.; Ekundayo, O.; Walker, T.M.; Schmidt, J.M.; Setzer, W.N. Studies on the essential oils composition, antibacterial and cytotoxicity of Eugenia uniflora L. Int. J. Aromather. 2005, 15, 147-152.

26. Melo, R.M.; Corrêa, F.S.V.; Amorim, A.C.L.; Miranda, A.L.P.; Rezende, C.M. Identification of impact aroma compounds in Eugenia uniflora L. (Brazilian pitangueira) leaf essential oil. J. Braz. Chem. Soc. 2007, 18, 179-183.

27. El-Shabrawy, A.O. Essential oil composition and tannin contents of the leaves of Eugenia uniflora L. grown in Egypt. Bull. Fac. Pharm. Cairo Univ. 1995, 33, 17-21.

28. Morais, S.M.; Craveiro, A.A.; Machado, M.I.L.; Alencar, J.W.; Matos, J.A. Volatiles constituents of Eugenia uniflora leaf oil from Northeastern Brazil. J. Essent. Oil Res. 1996, 8, 449-451.

29. Costa, D.P.; Santos, S.C.; Seraphin, J.C.; Ferri, P.H. Seasonal variability of essential oils of Eugenia uniflora leaves. J. Braz. Chem. Soc. 2009, 20, 1287-1293.

30. Espinel-Ingroff, A. In vitro antifungal activities of anidulafungin and micafungin, licensed agents and the investigational triazole posaconazole as determined by NCCLS methods for 12,052 fungal isolates: Review of the literature. Rev. Iberoam. Micol. 2003, 20, 121-136. 
31. Marino, I.R.; Panarello, G.; Singh, N. Efficacy of Aspergillus galactomannan-directed preemptive therapy for the prevention of invasive aspergillosis in organ transplant recipients.Transpl. Infect. Dis. 2002, 4, 226-227.

32. Chorianopoulos, N.; Kalpoutzakis, E.; Aligiannis, N.; Mitaku, S.; Nychas, G.J.; Haroutounian, S.A. Essential oils of Satureja, Origanum, and Thymus species: Chemical composition and antibacterial activities against foodborne pathogens. J. Agric. Food Chem. 2004, 52, 8261-8267.

33. Gutierrez, J.; Rodriguez, G.; Barry-Ryan, C.; Bourke, P. Efficacy of plant essential oils against foodborne pathogens and spoilage bacteria associated with ready-to-eat vegetables: Antimicrobial and sensory screening. J. Food Prot. 2008, 71, 1846-1854.

34. Tiwari, B.K.; Valdramidis, V.P.; O’Donnell, C.P.; Muthukumarappan, K.; Bourke, P.; Cullen, P.J. Application of natural antimicrobials for food preservation. J. Agric. Food Chem. 2009, 57, 5987-6000.

35. Sokmen, A.; Vardar-Unlu, G.; Polissiou, M.; Daferera, D.; Sokmen, M.; Donmez, E. Antimicrobial activity of essential oil and methanol extracts of Achillea sintenisii Hub. Mor. (Asteraceae). Phytother. Res. 2003, 17, 1005-1010.

36. Blanco, J.L.; Garcia, M.E. Immune response to fungal infections. Vet. Immunol. Immunopathol. 2008, 125, 47-70.

37. Nielsen, K.; Heitman, J. Sex and virulence of human pathogenic fungi. Adv. Genet. 2007, 57, 143-173.

38. Tamae, C.; Liu, A.; Kim, K.; Sitz, D.; Hong, J.; Becket, E.; Bui, A.; Solaimani, P.; Tran, K.P.; Yang, H.; Miller, J.H. Determination of antibiotic hypersensitivity among 4,000 single-geneknockout mutants of Escherichia coli. J. Bacteriol. 2008, 190, 5981-5988.

39. Adams, R.P. Identification of Essential Components by Gas Chromatography/Mass Spectroscopy; Allured Corp.: Carol Stream, IL, USA, 1995.

Sample Availability: Samples of the essential oils are available from the authors.

(C) 2011 by the authors; licensee MDPI, Basel, Switzerland. This article is an open access article distributed under the terms and conditions of the Creative Commons Attribution license (http://creativecommons.org/licenses/by/3.0/). 